\title{
Mineral Resources of the Little Owyhee River Wilderness Study Area, Owyhee County, Idaho
}

\section{U.S. GEOLOGICAL SURVEY BULLETIN 1719-C}

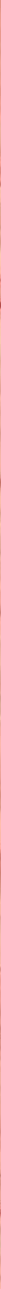



Chapter C

\section{Mineral Resources of the Little Owyhee River Wilderness Study Area, Owyhee County, Idaho}

By JAY A. ACH and HARLEY D. KING U.S. Geological Survey

ALAN R. BUEHLER and DONALD O. CAPSTICK U.S. Bureau of Mines 


\title{
DEPARTMENT OF THE INTERIOR DONALD PAUL HODEL, Secretary
}

\author{
U.S. GEOLOGICAL SURVEY
}

Dallas L. Peck, Director

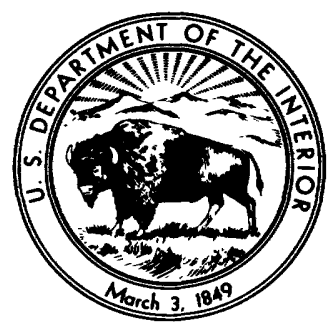

For sale by the

Books and Open-File Reports Section

U.S. Geological Survey

Federal Center, Box 25425

Denver, CO 80225

Library of Congress Cataloging-in-Publication Data

Mineral resources of the Little Owyhee River Wilderness study area, Owyhee County, Idaho

U.S. Geological Survey Bulletin 1719-C

Bibliography

Supt. of Docs. No.: I 19.3:1719-C

1. Mines and mineral resources-Idaho-Little

Owyhee River Wilderness. 2. Geology-ldaho-Little

Owyhee River Wilderness. 3. Little Owyhee River

Wilderness (Idaho) I. Ach, Jay A. II. Series.

QE75.B9 No. B1719-C

$557.3 \mathrm{~s}$

$86-600161$

[TN24.12]

$\left[553^{\prime} .09796^{\prime} 21\right]$ 


\section{STUDIES RELATED TO WILDERNESS}

\section{Bureau of Land Management Wilderness Study Areas}

The Federal Land Policy and Management Act (Public Law 94-579, October 21, 1976) requires the U.S. Geological Survey and the U.S. Bureau of Mines to conduct mineral surveys of certain areas to determine the mineral values, if any, that may be present. Results must be made available to the public and be submitted to the President and the Congress. This report presents the results of a mineral survey of the Little Owyhee River Wilderness Study Area (ID-016-48C), Owyhee County, Idaho. 



\section{CONTENTS}

Summary C1

Abstract 1

Character and setting 1

Identified resources 1

Mineral resource potential 1

Introduction 1

Area description 1

Previous and present investigations $\mathbf{3}$

Acknow ledgments 3

Appraisal of identified resources 3

History and production $\mathbf{3}$

Mineral deposits 3

Assessment of mineral resource potential 5

Geology 5

Geochemical studies 5

Conclusions 6

References cited 7

Appendix 1. Definition of levels of mineral resource potential and certainty of assessment 9

\section{FIGURES}

1. Index map showing location of the Little Owyhee River Wilderness Study Area, Owyhee County, Iduho C2

2. Map showing mineral resource potential and geology of the Little Owyhee River Wilderness Study Area, Owyhee County, Idaho 4

3. Major elements of mineral resource potential/certainty classification 9

\section{TABLE}

1. Mines, prospects, and mineralized areas in and adjacent to the Little Owyhee River Wilderness Study Area $\mathrm{ClO}$ 



\title{
Mineral Resources of the Little Owyhee River Wilderness Study Area, Owyhee County, Idaho
}

\author{
By Jay A. Ach and Harley D. King \\ U.S. Geological Survey
}

\author{
Alan R. Buehler and Donald O. Capstick \\ U.S. Bureau of Mines
}

\section{SUMMARY}

\begin{abstract}
The Little Owyhee River Wilderness Study Area (ID-016-48C) encompasses 8,460 acres in the extreme southwest corner of Idaho along the canyon of the Little Owyhee River. Throughout this report, "wilderness study area" and "study area" refer to the 8,460 acres on which mineral surveys were completed. Fieldwork for this report was carried out between 1983 and 1985. No mines, prospects, or mining claims were located inside the study area, and no mineral resources were identified. The wilderness study area has a low mineral resource potential for silver, gold, and mercury. There is also a low mineral resource potential for the nonmetallic commodities diatomite and zeolites.
\end{abstract}

\section{Character and Setting}

The Little Owyhee River Wildernesss Study Area is located $8 \mathrm{mi}$ northeast of the southwest corner of Idaho (fig. 1). The terrain consists of a flat to gently rolling plateau deeply incised by the spectacular canyon cut by the Little Owyhee River to depths of $800 \mathrm{ft}$. The surface of the plateau is defined by the thin flows of the Banbury Basalt of late Miocene age. Beneath surficial flows, additional basalt flows are interbedded with lacustrine sediments. The Banbury Basalt and lacustrine sediments overlie the Swisher Mountain Tuff, a rhyolitic ash-flow tuff of middle Miocene age. The Swisher Mountain Tuf $f$ is the oldest unit exposed in the study area. (See Ekren and others, 1981, 1984.)

\section{Identified Resources}

No known mines, prospects, or mining claims are located within the study area, but parts of the study area are included in petroleum and natural gas leases or lease applications. There are no identified mineral or energy resources within the study area.

\section{Mineral Resource Potential}

The Little Owyhee River Wilderness Study Area does not lie within any established mining district.

The northeastern part of the wilderness study area has low mineral resource potential for both epithermal silver-gold and epithermal mercury deposits. This is indicated by weak geochemical anomalies in rock samples from within the study area and the presence of small areas of altered rock and additional geochemical anomalies immediately outside the study area.

Some geochemical evidence of the presence of tin was gathered to the west of the study area, although the geologic environment is not favorable for a tin resource in that area. However, no geochemical evidence of tin was found within the study area and the wilderness study area is considered to have no mineral resource potential for tin.

The mineral resource potential for the nonmetallic commodities diatomite and zeolites is also considered low in the wilderness study area. Evidence of the occurrence of these minerals exists 1-1.5 mi outside the study area in sedimentary rocks, but little evidence of their existence within the study area was found.

\section{INTRODUCTION}

\section{Area Description}

The Little Owyhee River Wilderness Study Area (ID-016-48C) consists of 8,460 acres recommended suitable for wilderness consideration out of 24,677 acres originally considered. The study area is located $8 \mathrm{mi}$ northeast of the southwestern corner of Idaho 


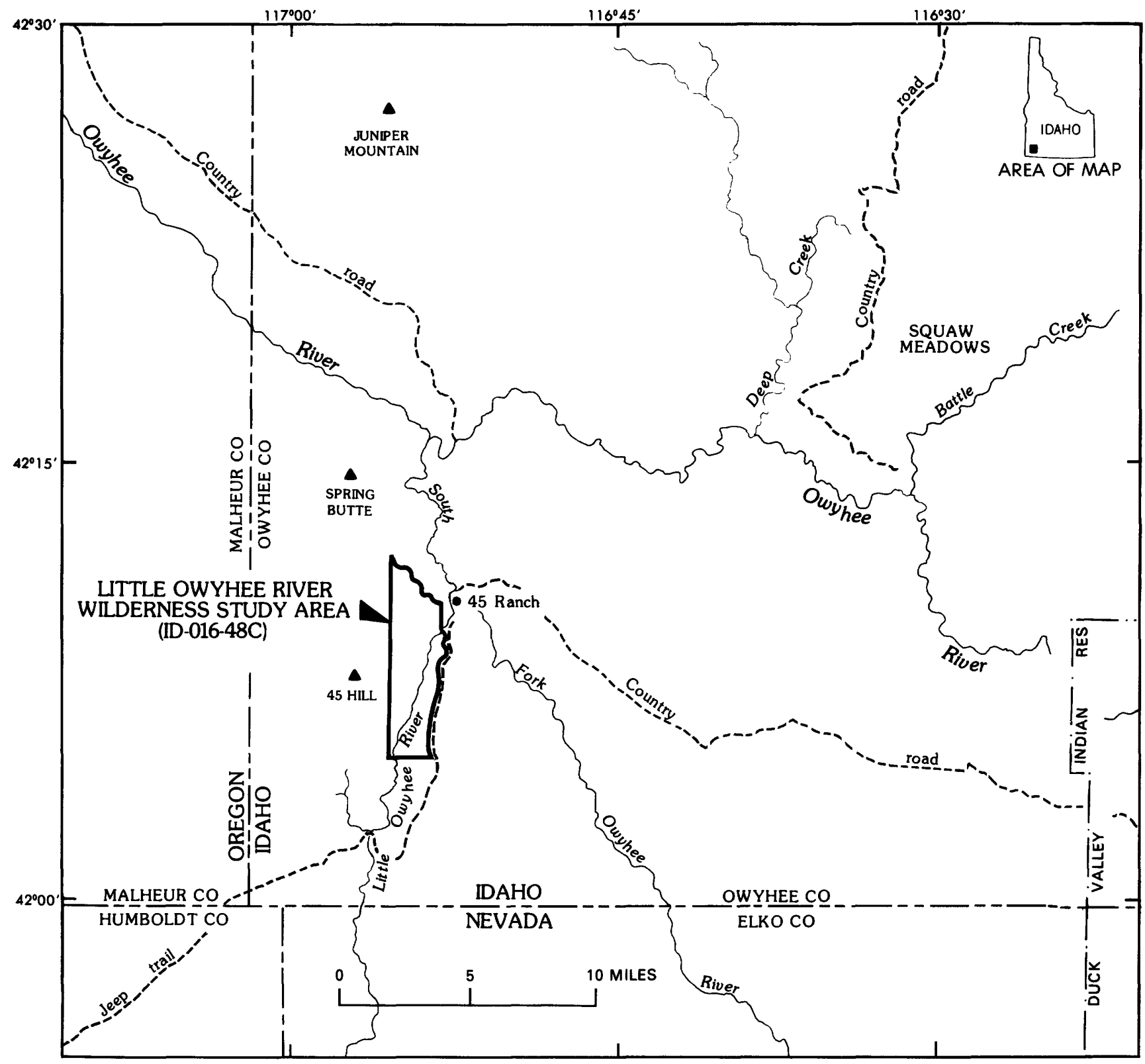

Figure 1. Index map showing location of the Little Owyhee River Wilderness Study Area, Owyhee County, Idaho. 
(fig. 1) and includes a part of the Owyhee Plateau, a flat to gently rolling plateau with an average elevation of about $5,200 \mathrm{ft}$ within the study area. The Owyhee Plateau is deeply incised by the spectacular and precipitous canyons of the various branches of the Owyhee River system. The part of the plateau included in this wilderness study area surrounds the canyon cut by the Little Owyhee River, immediately upstream of that river's junction with the South Fork of the Owyhee River. Within the wilderness study area, the canyon of the Little Owyhee River reaches depths of $800 \mathrm{ft}$ below the surrounding countryside. The climate is arid to semiarid, with an average of less than ten inches of precipitation a year. The vegetation is sparse, consisting of sagebrush, various range grasses, and the odd juniper tree.

Access to the study area is by approximately 41 mi of graded dirt and gravel roads that lead west from Idaho State Highway 51 through the Duck Valley Indian Reservation to the 45 Ranch (fig. 1). From the ranch, the study area can be reached by the dirt road that bounds the area on the east.

\section{Previous and Present Investigations}

Geologic mapping and studies by Ekren and others $(1981,1984)$ provided the basis for the mapping for this study. Additional information on the general regional geology is contained in Walker and Repenning (1966), Kittleman and others (1967), Hope and Coats (1976), and Bonnichsen and Breckenridge (1982). Previous reconnaissance studies of the geology and the energy and mineral resources of wilderness study areas in the region were carried out by Mathews and Blackburn (1983a, b). The uranium resource potential for the region was evaluated as part of the National Uranium Resource Evaluation (NURE) program (Berry and others, 1982; Geodata, 1980).

The U.S. Geological Survey carried out field investigations in the study area during the summers of 1984 and 1985. The work included field checking of existing geologic maps, new mapping where necessary, and geochemical sampling. Rock samples were collected from areas of observed alteration and from each lithologic unit in order to obtain information about trace-element signatures associated with potentially mineralized areas and to provide traceelement background data.

The U.S. Bureau of Mines conducted a library search for information on mines and prospects within the study area. These data were supplemented by information from Owyhee County, U.S. Bureau of Land Management, and U.S. Bureau of Mines records. Field studies by U.S. Bureau of Mines personnel were carried out in 1984 (Buehler and Capstick, 1985). One hundred thirty-nine rock samples and 20 stream-sediment samples were collected from areas of possible mineralization within and immediately outside the study area. Samples were analyzed by fire-assay. atomic-absorption, and inductively coupled argonplasma spectrophotometric methods. Selected rock samples of lacustrine and tuffaceous sediments were analyzed by X-ray diffraction for zeolites or examined microscopically and ignition-tested for diatomite. Complete analytical data are on file at the U.S.
Bureau of Mines, Western Field Operations Center, Spokane, Washington 99202.

\section{Acknowledgments}

The staff of the Boise District Office of the U.S. Bureau of Land Management provided logistical support, information, and the use of the fine U.S. Bureau of Land Management camp at Mud Flat. Ben Glanville, owner of the 45 Ranch, and Sonny and Judy Smith, caretakers of the 45 Ranch, graciously provided information, access, and many courtesies.

\section{APPRAISAL OF IDENTIFIED RESOURCES}

By Alan R. Buehler and Donald O. Capstick, U.S. Bureau of Mines

\section{History and Production}

The Little Owyhee River Wilderness Study Area is not within a mining district and there are no mines or prospects within or near the area. Minor. unrecorded production of jasper, chalcedony, and common opal suitable for lapidary purposes or as specimens has occurred. The only known production near the wilderness study area is of several hundred pounds of this material produced from the Lu Lew prospect (P.M. Gabby, unpub. data), a rock collectors' locality located approximately $0.4 \mathrm{mi}$ west of the 45 Ranch (fig. 2)(see table 1).

\section{Mineral Deposits}

No diatomite or zeolites were found in the wilderness study area. However, nearby areas show evidence of zeolitic alteration or diatomite deposition. These occur within the lacustrine sediments beneath and interbedded with the Banbury Basalt flows and the tuffaceous horizons lying beneath the flows. At one location $13 / 4 \mathrm{mi}$ south-southwest of the southwest corner of the study area (locality A, fig. 2), a 100-ft-thick section of zeolitic ash beds averaged 42 percent clinoptilolite (a zeolite mineral) (Table 1 ). Development of the zeolite minerals here would be nearly impossible because of the 200-300 ft of sediment and basalt overburden at this locality. At another location $1.3 \mathrm{mi}$ west of the northern end of the study area (locality B, fig. 2), an exposure of lacustrine sediments contains diatomite, although much of it is of unsuitable quality (Table 1 ).

Stream-sediment samples from the Little Owyhee River show only minor, very fine placer gold, typical of the Owyhee River region (highest value $\$ 0.03 / \mathrm{yd}^{3}$, average value $\$ 0.016 / \mathrm{yd}^{3}$; calculated with gold at $\$ 400.00 / \mathrm{oz})$.

Sand and gravel deposits suitable for construction use occur in the wilderness study area, but larger, more accessible deposits are widely a vailable outside the study area. 


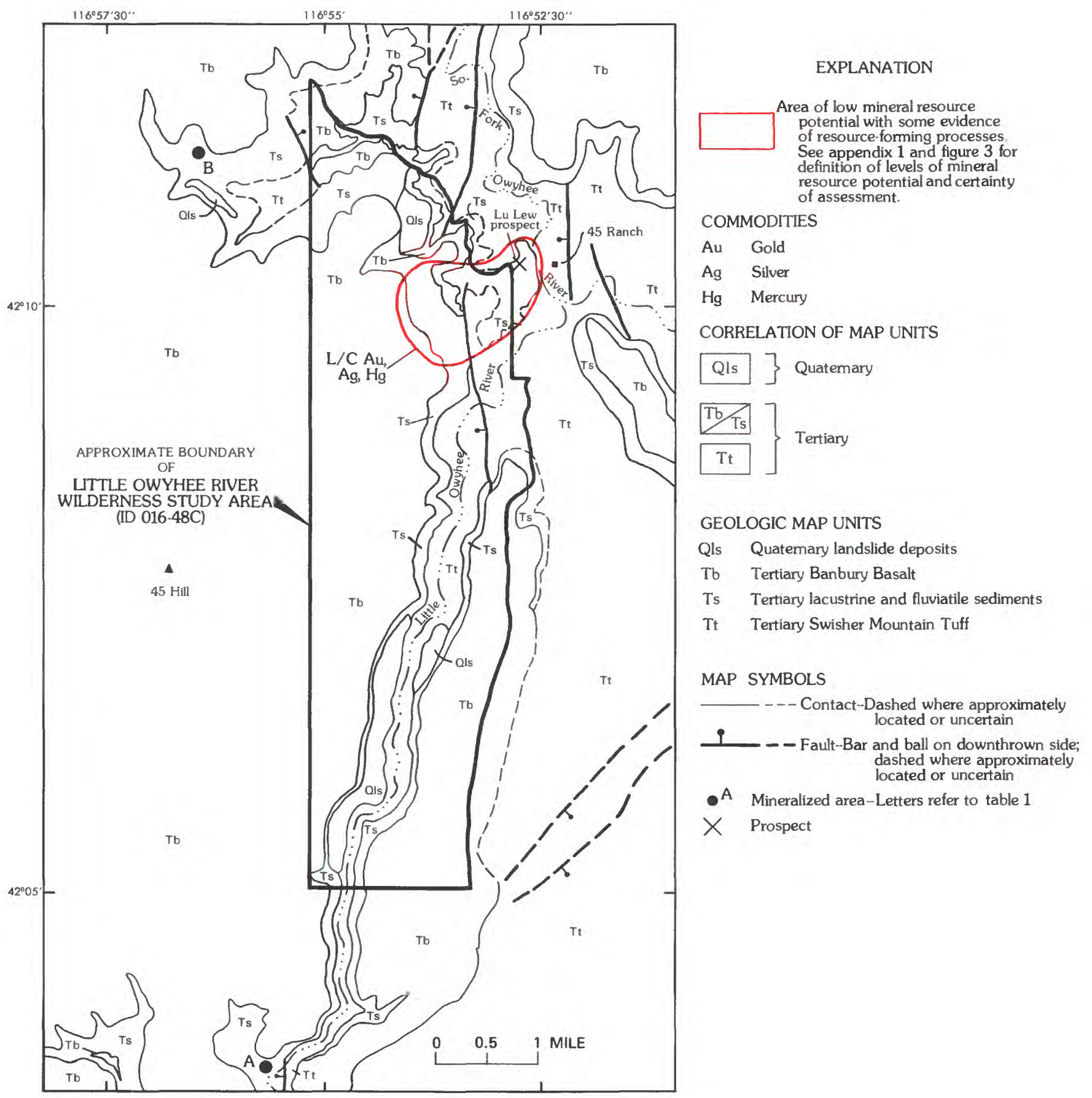

Figure 2. Map showing mineral resource potential and geology of the Little Owyhee River Wilderness Study Area, Owyhee County, Idaho. 
ASSESSMENT OF MINERAL RESOURCE POTENTIAL

By Jay A. Ach and Harley D. King, U.S. Geological $\underline{\text { Survey }}$

\section{Geology}

Pre-Miocene basement rocks are not exposed within or near the Little Owyhee River Wilderness Study Area, but may consist of Cretaceous granites overlain by mixed volcanic rocks of Eocene and Oligocene age. The oldest unit exposed in the study area is the middle Miocene Swisher Mountain Tuff. It is overlain by the late Miocene Banbury Basalt and associated int erbedded sediments.

Cretaceous granitic plutons of the Idaho Batholith, which intrude metasedimentary rocks of pre-Cretaceous age, crop out on South Mountain and in the Owyhee Mountains, $35 \mathrm{mi}$ north and $45 \mathrm{mi}$ northnortheast. respectively, of the study area. These outcrops of basement rocks are the closest to the study area; however, similar basement rocks may extend beneath the area (Ekren and others, 1984). In the Owyhee Mountains, locally preserved Eocene intermediate lavas and quartz latite tuffs, and Oligocene olivine basalt and andesite of restricted extent overlie the Cretaceous granites. The regional extent of all of these lavas is conjectural, and they may or may not overlie basement rocks within the study area.

The oldest unit exposed in the wilderness study area is the middle Miocene Swisher Mountain Tuff (fig. 2 ), with reported potassium-argon ages of $14.2 \pm 0.4$ m.y. (Armstrong and others, 1980), and 13.1 \pm 0.2 m.y. and $13.8 \pm 0.4 \mathrm{~m} . \mathrm{y}$. (Neill, 1975). Ekren and others (1984) assumed an age of $13.85 \mathrm{~m} . \mathrm{y}$. The tuff is a flow-foliated compound cooling unit of rhyolitic ashflow tuff of calc-alkalic (Ekren and others, 1984) or possibly peralkaline (J.J. Rytuba, oral comm., 1985) chemistry. The unit ranges in color from light grey to light purple- or pink-grey. Phenocrysts total approximately 15 percent and include plagioclase (62 percent of total), alkali feldspar (15 percent), pigeonite ( 20 percent), and opaque oxides ( 3 percent) (Ekren and others, 1984). An upper vitrophyre is well developed in the study area; additional vitrophyres within the unit are found at other locales. The maximum exposed thickness of the Swisher Mountain Tuff in the study area is about $650 \mathrm{ft}$, but the base is not exposed. Ekren and others (1984) consider Juniper Mountain, $12 \mathrm{mi}$ to the north of the study area (fig. 1), to be the eruptive center for the Swisher Mountain Tuff. the second oldest of five tuffs er upted from this center over a time span of at least two million years. These eruptions did not produce a caldera or other eruption-related subsidence features.

Late Miocene basalt flows and interbedded sediments overlie the Swisher Mountain Tuff. The basalt was assigned to the Banbury Basalt by Ekren and others (1984), which gives potassium-argon ages of 8.0 to $10.5 \mathrm{~m} . \mathrm{y}$. (Armstrong and others, 1975). These numerous, thin flows (generally less than $50 \mathrm{ft}$ thick) are olivine tholeiites (Ekren and others, 1984) and contain small quantities of small phenocrysts (less than
$2 \mathrm{~mm}$ ) of plagioclase and olivine in a very fine-grained matrix of int ergranular to ophitic

texture. Small vesicles, less than $4 \mathrm{~mm}$ in diameter, are common, some of which are partially filled with secondary silica or zeolites. At least some of these flows are of local derivation, and were erupted from 45 Hill and Spring But te, inferred vents (figs. 1, 2).

The white-to-buff sediments beneath and interbedded with the basalt flows are of lacustrine and fluviatile origin. The part of the sediments beneath the basalts contains some beds of tuffaceous material. The sediments are generally composed of fairly well-bedded clay- to coarse sand-sized material, with lenses of gravel and rare cobbles occasionally found in the fluvial deposits. The combined thickness of the sediments and the Banbury Basalt varies from 300 to $600 \mathrm{ft}$ within the study area.

Quaternary deposits consist of alluvium in the canyon bottoms, talus on canyon slopes, and fairly large landslide and slump deposits at some locations along the canyon sides.

\section{Geochemical Studies}

A reconnaissance geochemical study was made based on analysis and evaluation of stream sediments, the non-magnetic fraction of heavy-mineral concentrates from stream sediments, and rock samples. The stream-sediment and concentrate samples contain material derived from major rock units of the drainage basin. Sampled drainage basins range in area from less than one to several square miles.

All 39 stream-sediment samples, 24 heavymineral-concentrate samples, and 16 rock samples were analyzed for 31 elements by six-step semiquantitative emission-spectrographic methods (Myers and others, 1961; Grimes and Marranzino, 1968), with additional analyses by atomic-absorption spectroscopy and inductively coupled argon plasmaatomic emission spectroscopy (ICAP-AES). These analyses identify drainages with anomalously high concentrations of metallic and metal-related elements. Anomalous values were determined by inspection of histograms and noting enrichment relative to crustal abundances.

Stream-sediment samples and heavy-mineralconcentrate samples show no geochemical anomalies within the wilderness study area; however, heavymineral concentrates from some drainages of $45 \mathrm{Hill}$, $1.5 \mathrm{mi}$ west of the wilderness study area, show anomalously high concentrations of tin ( 3 samples, 500 to $1,000 \mathrm{ppm}$ ). Microscopic examination of those concentrates revealed the presence of cassiterite, the primary tin ore. Tin mineralization is most commonly associated with granites, although epithermal vein deposits of cassiterite are mined from silicic volcanic rocks in Bolivia and Mexico. The veins there occur in rhyodacite-to-rhyolite stocks, plugs, and breccia pipes interpreted to represent volcanic vents (Hutchinson, 1983). There are no recorded instances of tin deposits associated with basalt, however, and the drainages near the wilderness study area that have anomalously high tin values are entirely underlain by basalt. The likelihood that these anomalies are related to a tin 
resource is therefore very remote.

Widely scattered tin anomalies in heavy-mineral concentrates are relatively common elsewhere in the Owyhee Plateau (H.D. King, unpub. data). Peralkaline rhyolites are commonly enriched in lithophile elements, including tin (MacDonald and Bailey, 1973). The Swisher Mountain Tuff and other peralkaline rhyolitic tuffs occurring in the region are probably the source of the tin detected regionally; however, the source of the tin detected in the 45 Hill drainages is unknown.

Rock samples within and immediately outside the wilderness study area just west of the 45 Ranch show weak-to-moderate geochemical anomalies for arsenic (As) (6 and $17 \mathrm{ppm}$ ), antimony (Sb) (12 and $17 \mathrm{ppm}$ ), molybdenum (Mo) $(5,7$, and $15 \mathrm{ppm})$, and possibly mercury $(\mathrm{Hg})(0.07$ and $0.19 \mathrm{ppm})$. These samples are all from the tuffaceous sediments overlying the Swisher Mountain Tuff. Two samples of sediments of the same unit from outside the study area (near the Lu Lew prospect and $0.2 \mathrm{mi}$ south-southeast of the prospect area) are of locally brightly stained rock that has been very locally brecciated, silicified, and cut by thin goethite veins. These two samples produced the strongest geochemical anomalies, with one containing anomalous quantities of $\mathrm{As}, \mathrm{Sb}$. Mo, and $\mathrm{Hg}$ and the other containing anomalous As and Mo only. This rock occurs in only two small outcrops that seem to lie on the local north-northwest fault trend, suggesting that the alteration was fault-controlled. Such visibly altered rock is not found within the study area, although the three samples with slightly anomalously high values ( $\mathrm{Sb}$ in one, Mo in another, and $\mathrm{Hg}$ in the third) indicate that some alteration or mineralization may have occurred. The locus of mineralization probably lies outside the wilderness study area in the visibly altered rocks to the east.

Anomalously high values for $\mathrm{As}, \mathrm{Sb}$, Mo, and $\mathrm{Hg}$ are often associated with epithermal mercury mineralization (Rytuba and Glanzman, 1979) or epithermal silver-gold mineralization of the low-sulfur type (Bonham, 1984; Bonham and Tingley. 1984), both of which occur within silicic volcanic or related host rocks. Important mineral deposits of these two different types are usually associated with the complex structures found in volcanic eruptive centers. These structures include strongly persistent fracture systems, especially caldera-related ring fractures and grabens, and volcanic domes and plugs in complexly faulted areas (Berger, 1982). Although minor faults of limited of fset are present in the study area, such complex structures are absent, and the study area is several miles removed from Juniper Mountain, the postulated eruptive center for the Swisher Mountain Tuff. Even though the overall geologic environment of the study area is permissive for epithermal silver-gold and epithermal mercury deposits, it is not a highly favorable environment because of the study area's distance from the Juniper Mountain eruptive center and the corresponding absence of complex structures in the area.

Previous regional uranium surveys, which included aerial gamma-ray emission studies (Berry and others, 1982; Geodata, 1980), found no indications of uranium concentrations in the vicinity of the wilderness study area.

\section{Conclusions}

Geological and geochemical data indicate that the Little Owyhee River Wilderness Study Area has low resource potential for epithermal mercury deposits and epithermal silver-gold deposits with a $\mathrm{C}$ certainty level. The resource potential for zeolites and diatomite is also low with a $\mathrm{C}$ certainty level. The resource potential for petroleum and natural gas is unknown (certainty level A), but their occurrence within the study area is very unlikely. The resource potential for geothermal energy is low, with a C certainty level. See Appendix 1 and Figure 3 for definitions of levels of mineral resource potential and certainty.

The investigations by the U.S. Geological Survey and the U.S. Bureau of Mines indicate that there is low mineral resource potential for epithermal silver-gold and epithermal mercury in the area just west of the 45 Ranch (fig. 2). A certainty level of $\mathrm{C}$ is assigned because the area of strongest alteration, denoted by the strongest geochemical anomalies and most visibly altered outcrops, lies outside the study area. This alteration may be fault-controlled; if so, local fault trends indicate that the trend of the inferred fault and the alteration involved do not intersect the study area. Geologic mapping indicates that the tuffaceous lacustrine sediments, the host rock for the alteration, are very thin ( 0 to $100 \mathrm{ft}$ ) in the area around the visibly altered zone. Therefore, the alteration (and any associated mineralized zone) must necessarily be of very limited vertical extent, assuming the alteration is indeed confined to the sediments. The only possible indication of this type of mineralization within the study area is the presence of slightly anomalous geochemical values in rock samples collected from within the indicated area of low potential (fig. 2).

Although traces of zeolites and diatomite occur in the sediments associated with the Banbury Basalt in the wilderness study area, and somewhat higher-grade accumulations are found within two miles of the study area, the resource potential of these two minerals is probably poor. A low resource potential with a certainty level of $C$ is assigned because no evidence of deposits of suitable purity was found within or near the study area. Additionally, the traces of these minerals observed within the study area do not seem to be of great thickness or large lateral extent. Development of any deposit of either of these minerals, if they existed, would be nearly impossible because of the 100 to $400 \mathrm{ft}$ of basalt and sediment overburden that would need to be removed.

Sand and gravel deposits suitable for construction use occur in the wilderness study area. Because similar materials of equal or better quality are abundant closer to local markets, and the probable costs of mining exceed the present market value of these materials, their future development is highly unlikely.

Geologic data indicate a low probability for the occurrence of petroleum and natural gas in the Cenozoic rocks of the wilderness study area. Evidence for hydrocarbon potential is negligible; the volcanic rocks and lacustrine and fluviatile sedimentary strata immediately underlying the study area might include 
suitable reservoir rocks, but lack hydrocarbon source beds. The nature of the basement rocks is conjectural, however, and therefore the hydrocarbon resource potential is considered unknown, certainty level A.

Geothermal energy resource potential for the wilderness study area is low with a C certainty level. There is no evidence of geothermal activity in or near the study area. Previous regional geothermal surveys have not indicated any geothermal potential for the area (Muffler, 1979; Reed, 1983), but the absence of wells in the study area and surrounding region makes a survey of local groundwater temperatures impossible (see Bliss, 1983a, b, c). The existence of a geothermal resource is considered highly unlikely.

This assessment of mineral resource potential for the Little Owyhee River Wilderness Study Area was completed November, 1985.

\section{REFERENCES CITED}

Armstrong, R.L., Harakal, J.E., and Neill, W.M., 1980, $\mathrm{K}$-Ar dating of Snake River Plain (Idaho) volcanic rocks - new results: Isochron/West, no. 27, p. 510.

Armstrong, R.L., Leeman, W.P., and Malde, H.E., 1975, K-Ar dating, Quaternary and Neogene volcanic rocks of the Snake River Plain, Idaho: American Journal of Science, v. 275, p. 225-251.

Berger, B.R., 1982, The geological attributes of AuAg-base metal epithermal deposits; in Erickson, R.L., ed., Characteristics of mineral deposit occurrences: U.S. Geological Survey Open-File Report 82-795, 248 p.

Berry, M.R., Castor, S.B., and Robins, J.W. (Bendix Field Engineering Corporation), 1982, National uranium resource evaluation, Jordan Valley quadrangle, Oregon and Idaho (contract no. DEAC07-76GJ01664): U.S. Department of Energy Open-File Report PGJ/F-132(82), 33 p.

Bliss, J.D., 1983a, Idaho - Basic data for thermal springs and wells as recorded in GEOTHERM; Part A: U.S. Geological Survey Open-File Report 83$431 \mathrm{~A}, 63 \mathrm{p}$.

$1983 \mathrm{~b}$, Nevada - Basic data for thermal springs and wells as recorded in GEOTHERM; Part A: U.S. Geological Survey Open-File Report 83-433 A, $101 \mathrm{p}$.

1983c, Oregon - Basic data for thermal springs and wells as recorded in GEOTHERM: U.S. Geological Survey Open-File Report 83-435, 342 p.

Bonham, H.F. Jr., 1984, Three major types of epithermal precious-metal deposits: Abstracts with programs, Geological Society of America annual meeting, vol. 16 , no. 6, p. 449.

Bonham, H.F. Jr., and Tingley, J.V., 1984, Bulkminable gold deposits in Nevada: Abstracts with programs, Geological Society of America annual meeting, vol. 16, no. 6, p. 449.

Bonnichsen, W., and Breckenridge, R.M. eds., 1982, Cenozoic Geology of Idaho: Idaho Bureau of Mines and Geology Bulletin 26, 725 p.

Buehler, A.R., and Capstick, D.O., 1985, Mineral resources of the Little Owyhee River Wilderness Study Area (B.L.M. No. ID-16-48C), Owyhee
County, Idaho: U.S. Bureau of Mines Open File Report 77-85, 15 p.

Ekren, E.B., McIntyre, D.H., and Bennett, E.H., 1984, High-temperature, large-volume, lavalike ashflow tuffs without calderas in southwestern Idaho: U.S. Geological Survey Professional Paper 1272, $76 \mathrm{p}$.

Ekren, E.B., McIntyre, D.H., Bennett, E.H., and Malde, H.E., 1981, Geologic map of Owyhee County, Idaho, west of 116, West Longitude: U.S. Geological Survey Miscellaneous Geologic Investigations Map I-1256, scale 1:125,000.

Geodata International, Inc., 1980, Aerial radiometric and magnetic survey, national topographic map, Jordan Valley, Oregon/Idaho: prepared under Bendix Field Engineering Corp. subcontract no. 79-336-S, U.S. Department of Energy Open-File Report GJBX-95(80), 201 p.

Grimes, D.J., and Marranzino, A.P., 1968, Directcurrent arc and alternating-current spark emmission spectrographic field methods for the semiquantitative analysis of geologic materials: U.S. Geological Survey Circular 591, 6 p.

Hope, R.A., and Coats, R.R., 1976, Preliminary geologic map of Elko County, Nevada: U.S. Geological Survey Open-File Report 76-779, 6 pls.

Hutchinson, C.S., 1983, Economic deposits and their tectonic setting: New York, Wiley-Interscience, $365 \mathrm{p}$.

Kittleman, L.R., Green, A.R., Haddock, G.H., Hagood, A.R., Johnson, A.M., McMurray, J.M., Russel, R.G., and Weeden, H.A., 1967, Geologic map of the Owyhee region, Malheur County, Oregon: University of Oregon Museum of Natural History Bulletin 8, scale $1: 125,000$.

MacDonald, R., and Bailey, D.C., 1973, Chapter N, Chemistry of igneous rocks, Part 1, The chemistry of the peralkaline oversaturated obsidians; in Fleischer, M., ed., Data of geochemistry, sixth ed.: U.S. Geological Survey Professional Paper $440-\mathrm{N}-1,37 \mathrm{p}$.

Mathews, G.W., and Blackburn, W.H., 1983a, Assessment of geology, energy, and mineral (GEM) resources, Owyhee River GEM Resource Area, (ID-010-11), Ow yhee County, Idaho: prepared under U.S. Bureau of Land Management contract: YA-553-CT2-1042, TERRADATA, Lakew ood, Colorado, $37 \mathrm{p}$.

$1983 \mathrm{~b}$, Assessment of geology, energy, and mineral (GEM) resources, South Fork Ow yhee River GEM Resource Area, (ID-16-53/NV-010-103A), Elko County, Nevada: prepared under U.S. Bureau of Land Management contract: YA-553-CT2-1042, TERRADATA, Lakewood, Colorado, 33 p.

Muffler, L.J.P., ed., 1979, Assessment of geothermal resources of the United States - 1978: U.S. Geological Survey Circular 790, 163 p.

Myers, A.T., Haven, R.G., and Dunton, P.J., 1961, A spectrochemical method for the semiquantitative analysis of rocks, minerals, and ores: U.S. Geological Survey Bulletin 1084-I, p. 207-229.

Neill, W.M., 1975, Geology of the southeastern Ow yhee Mountains and environs, Owyhee County, Idaho: Stanford, Calif., Stanford University, unpub. MS thesis, $59 \mathrm{p}$. 
Reed, M.J., ed., 1983, Assessment of low-temperature geothermal resources of the United States 1982: U.S. Geological Survey Circular 892, 73 p.

Rytuba, J.J., and Glanzman, R.K., 1979, Relation of mercury, uranium, and lithium deposits to the McDermitt Caldera Complex, Nevada-Oregon, in Ridge, J.D., ed., Papers on mineral deposits of western North America: Nevada Bureau of Mines and Geology Report 33, p. 109-117.

Walker, G.W., and Repenning, C.A., 1966, Reconnaissance geologic map of the west half of the Jordan Valley quadrangle, Malheur County, Oregon: U.S. Geological Survey Miscellaneous Geologic Investigations Map I-457, scale $1: 250,000$. 


\section{APPENDIX 1. Definition of levels of mineral resource potential and certainty of assessment}

Mineral resource potential is defined as the likelihood of the presence of mineral resources in a defined area; it is not a measure of the amount of resources or their profitability.

Mineral resources are concentrations of naturally occurring solid, liquid, or gaseous materials in such form and amount that economic extraction of a commodity from the concentration is currently or potentially feasible.

Low mineral resource potential is assigned to areas where geologic, geochemical, and geophysical characteristics indicate a geologic environment where the existence of resources is unlikely. This level of potential embraces areas of dispersed mineralized rock as well as areas having few or no indications of mineralization. Assignment of low potential requires specific positive knowledge; it is not used as a catchall for areas where adequate data are lacking.

Moderate mineral resource potential is assigned to areas where geologic, geochemical, and geophysical characteristics indicate a geologic environment favorable for resource occurrence, where interpretations of data indicate a reasonable chance for resource accumulation, and where an application of genetic and (or) occurrence models indicates favorable ground.

High mineral resource potential is assigned to areas where geologic, geochemical, and geophysical characteristics indicate a geologic environment favorable for resources, where interpretations of data indicate a high likelihood for resource accumulation, where data support occurrence and (or) genetic models indicating presence of resources, and where evidence indicates that mineral concentration has taken place. Assignment of high resource potential requires positive knowledge that resource-forming processes have been active in at least part of the area; it does not require that occurrences or deposits be identified.

Unknown mineral resource potential is assigned to areas where the level of knowledge is so inadequate that classification of the area as high, moderate, or low would be misleading. The phrase "no mineral resource potential" applies only to a specific resource type in a well-defined area. 'This phrase is not used if there is the slightest possibility of resource occurrence; it is not appropriate as the summary rating for any area.

Expression of the certainty of the mineral resource assessment incorporates a consideration of (1) the adequacy of the geologic, geochemical, geophysical, and resource data base available at the time of the assessment, (2) the adequacy of the occurrence or the genetic model used as the basis for a specific evaluation, and (3) an evaluation of the likelihood that the expected mineral endowment of the area is, or could be, economically extractable.

Levels of certainty of assessment are denoted by letters, A-D (fig. 3).

A. The available data are not adequate to determine the level of mineral resource potential. Level $\mathrm{A}$ is used with an assignment of unknown mineral resource potential.

B. The available data are adequate to suggest the geologic environment and the level of mineral resource potential, but either evidence is insufficient to establish precisely the likelihood of resource occurrence, or occurrence and (or) genetic models are not known well enough for predictive resource assessinent.

C. The available data give a good indication of the geologic environment and the level of inineral resource potential, but additional evidence is needed to establish precisely the likelihood of resource occurrence, the activity of resource-forming processes, or available occurrence and (or) genetic models are minimal for predictive applications.

D. The available data clearly define the geologic environment and the level of mineral resource potential, and indicate the activity of resourceforming processes. Key evidence to interpret the presence or absence of specified types of resources is available, and occurrence and (or) genetic models are adequate for predictive resource assessment.

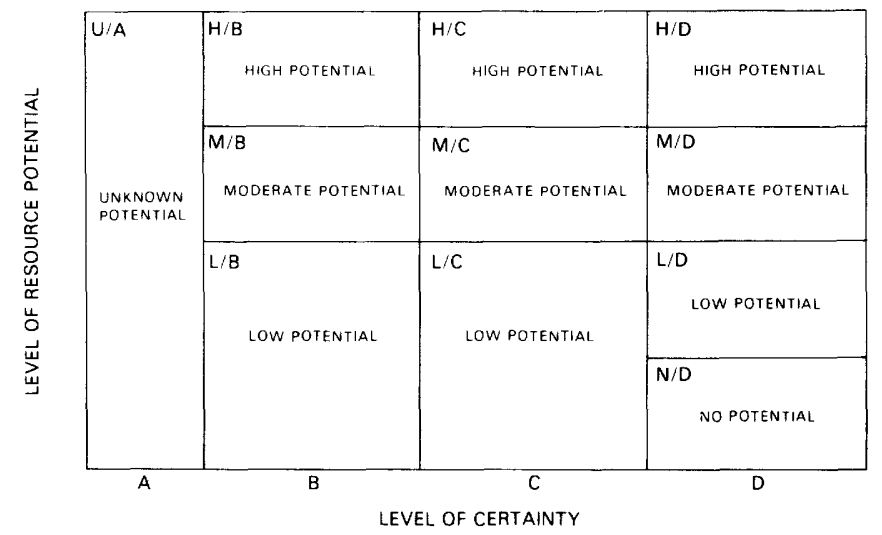

Figure 3. Major elements of mineral resource potential/certainty classification. 


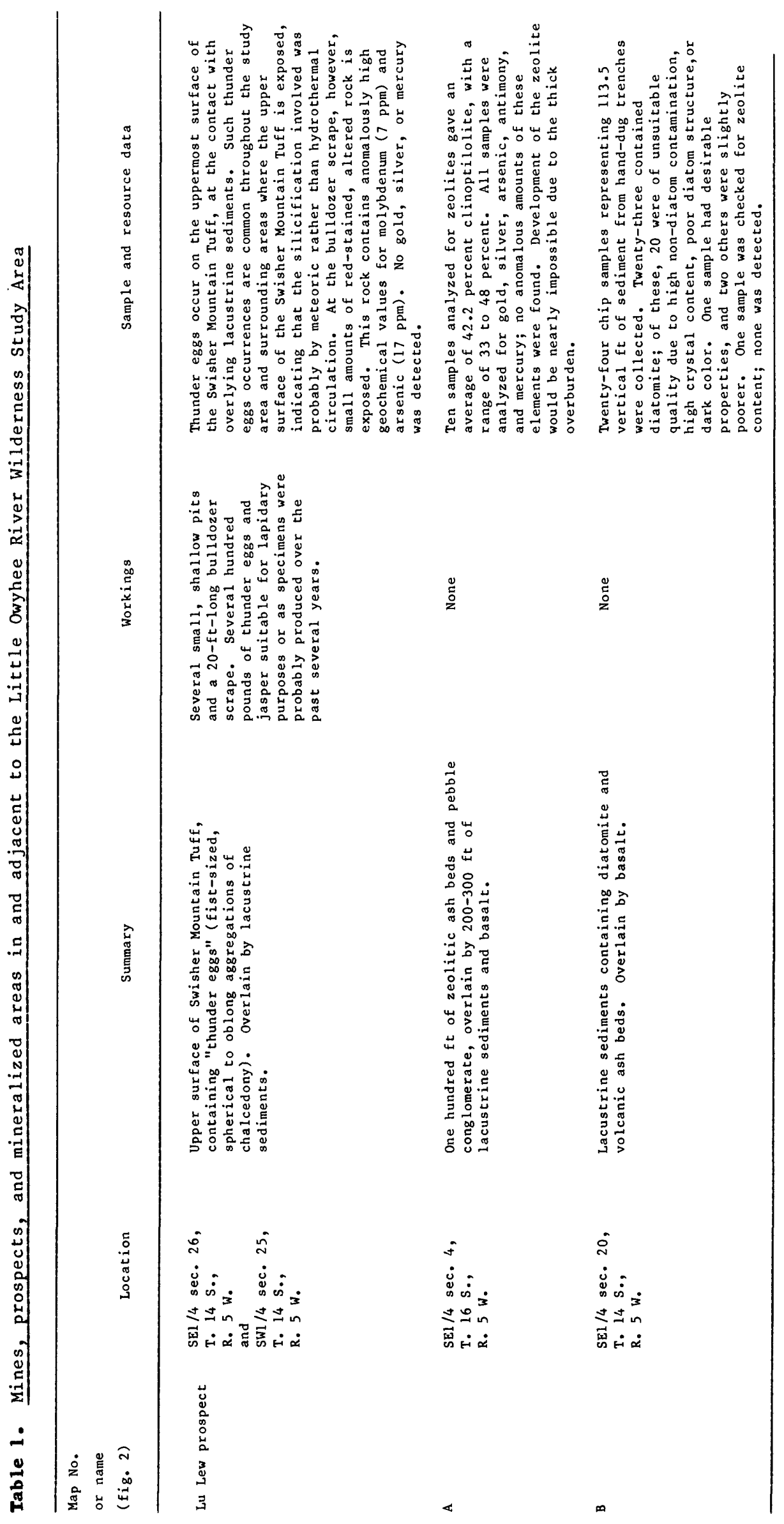





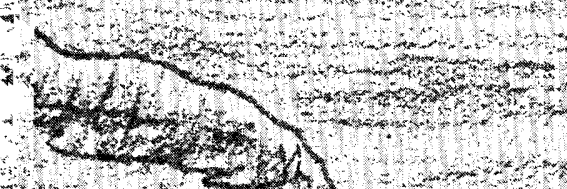

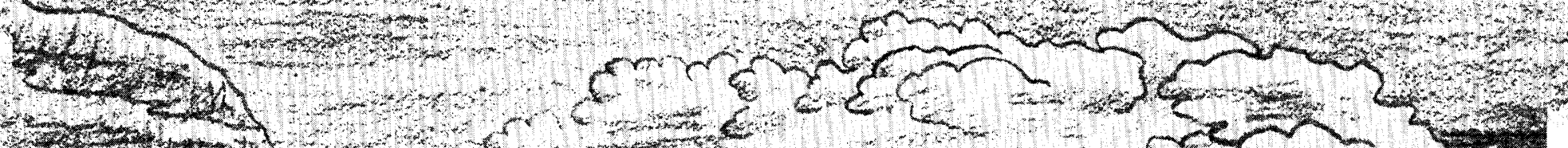

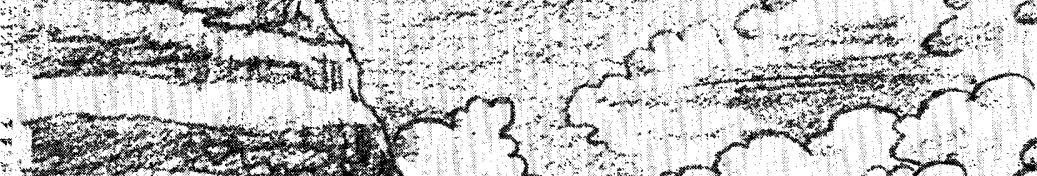

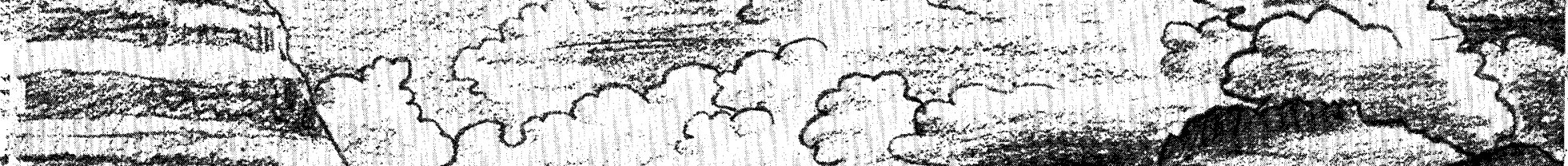

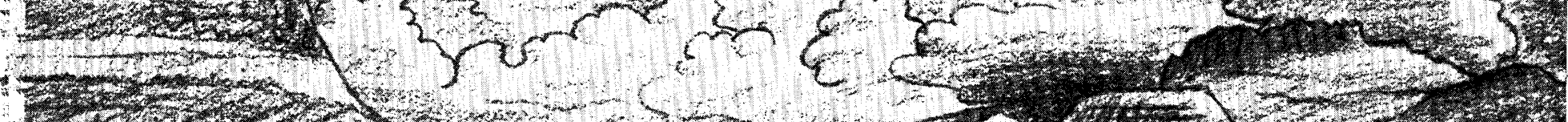
15.

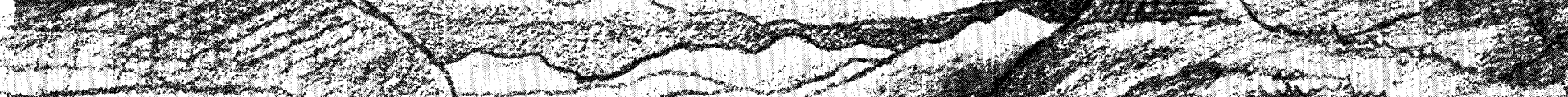

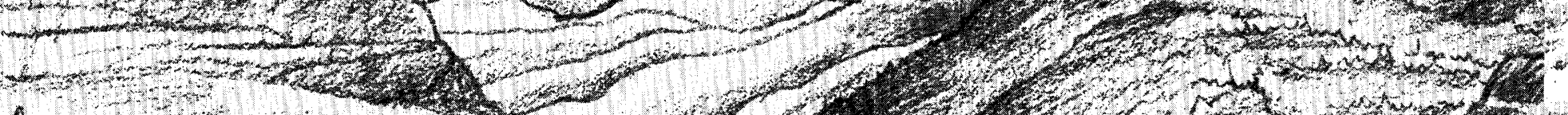
Q 4. W.

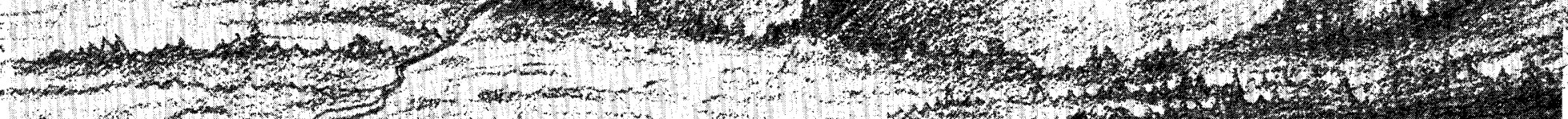

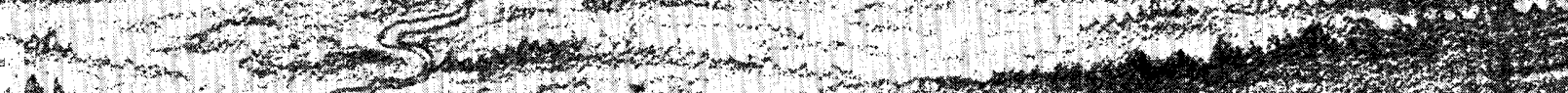

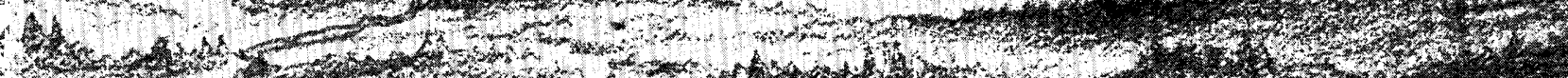

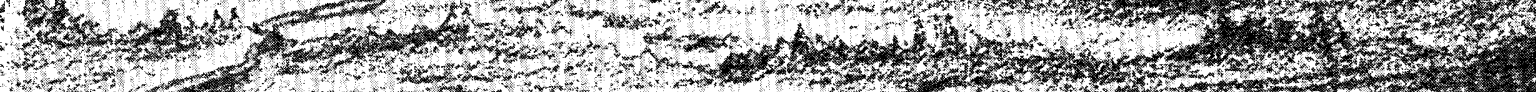

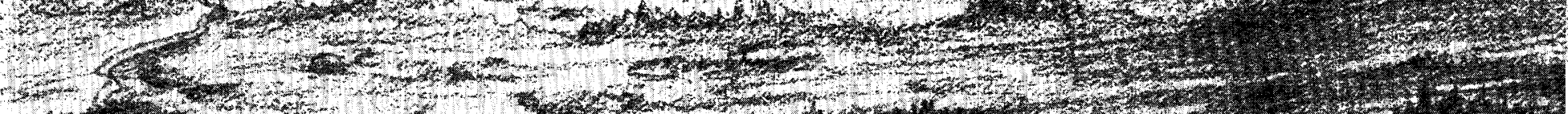

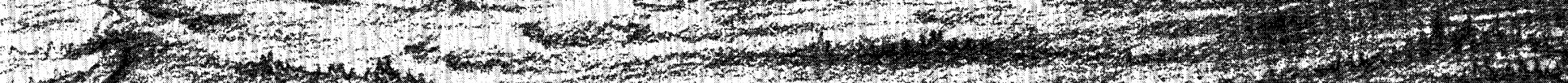

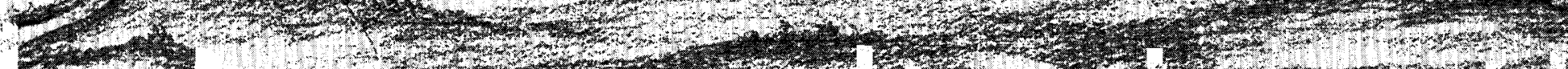

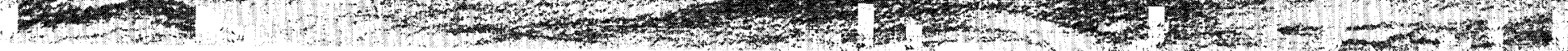

